\title{
Military Medical Ethics for the 21st Century
}

\author{
Ashgate May 2013; ISBN: 978-1-4094-3898-4.Edited by Michael L. Gross and Don Carrick
}

\author{
Brigadier General (Ret) Stephen N. Xenakis, MD*
}

In the span of just two generations, the United States has moved from condemning Nazi physicians at the Nuremberg Trials for their collusion with torture, inhuman experimentation, and cruel mistreatment, to justifying waterboarding in the pursuit of better intelligence. From force-feeding hunger strikers to assisting with enhanced interrogations, U.S. physicians, psychologists, and other health providers are implicated in professional misconduct that borders on torture and violates ethical principles and traditions. The leadership of the US Department of Defense justified employing healthcare providers in enhanced interrogations and related military missions by asserting that their responsibilities as soldiers trumped their ethical duties as physicians.

Across the globe, torture is practiced in many countries against political opponents as well as common criminals (or those alleged to be). In the past half century, countries with strong democracies that profess deep commitment to human rights, insidiously have legitimized the use of torture as a necessary weapon in fighting terrorism and domestic instability: the French occupy-

\footnotetext{
^) Correspondence to: snxenakis@hotmail.com
}

ing Algeria, the British battling the Irish Republican Army, the Israelis seeking to stop Palestinian attacks on civilians, and now the United States waging its war on terror.

Military Medical Ethics for the 21st Century covers the broad array of vexing issues arising with warfare in the modern era. The editors anchor this volume in their observation that the past two decades have seen a dramatic increase in asymmetric warfare. They observed that the law of armed conflict has not kept pace with the developments in insurgency and counterinsurgency conflicts. Add to those facts that medical technology has assumed an increasingly influential role. The convergence of these trends as well as changes in social and environmental conditions have set up a serious dilemma in medical ethics shadowing the health professions.

The editors have pulled together 29 respected authors with varied backgrounds and compiled a useful overview of the diverse field of medical ethics. The book is organized into three major sections helpful in guiding readers with different career interests: Battlefield Ethics; Military Medical Ethics, and New Technology; and Patient Rights, Research Ethics and Military Medical Ethics

Education. It is a useful reference for all healthcare professionals, even though the quality of writing and scholarship vary widely across the 300 pages. 
Part I on Battlefield Ethics covers the wars in Iraq and Afghanistan, the treatment of civilian casualties, the limits of impartiality, and principles of medical neutrality. Professor Gross has contributed an important chapter on the limitations of impartial treatment of soldiers wounded in combat. He challenges the imprimatur for impartial need-based medical care during war in exposing the competing demands for treating compatriots and accomplishing the military mission. He astutely observes the practical considerations facing clinicians engaged in combat side-by-side with family and friends that often trump ethics. As all doctors know, the realities of unity and friendship override any abstract principle of neutrality. My conversations with doctors having served in Afghanistan and Iraq have highlighted the tensions that arise when treating the different cohorts of casualties arriving at their doorsteps.

Part II tackles the emerging challenges of New Technology. Certainly, the unintended consequences of new technology became apparent in the industrial age and particularly with the use of the atomic bomb. But, the proliferation of advances in information technology, biologics, and genomic medicine has contributed to unprecedented opportunities for applications to warfare. Health professionals confront tough challenges in discerning if advancements should be used to develop weapon systems intended for harm and killing the enemy. This section covers enhancements to warfare including individual performance, policies for conducting research, and retrospective on the role of psychologists in designing programs of enhanced interrogation. Does acting in the "interest of national defense" conveniently disguise rationalizations for overriding fundamental ethical principles? Clearly, there are no easy answers.
Part III closes with a review of Rights and Ethics. Military physicians struggle with thorny issues of confidentiality and consent for treatment. Historically, military forces have required their service members to comply with prevention and vaccination programs that have not been fully tested in preparing for combat. The section closes with a chapter on medical education and teaching ethics to military physicians by Professor Edmund G. Howe at the Uniformed Services University of Health Sciences. I have helped teach that course on occasion and am impressed with the thought and preparation that Dr. Howe has put into it. The course is offered to second-year medical students with electives in the third and fourth year. Missing is a structured curriculum for actively serving officers, as well as a systematic review of ethics and medical practices in the American military since $9 / 11$. Various human rights groups have petitioned the Department of Defense to undertake a comprehensive and transparent review and involve outside physicians. To date, it has not happened.

Health professionals have historically been deeply engaged on the front lines of war. More than ever, physicians, health professionals, and legal experts across the globe, are seeing victims of cruel, inhuman, and degrading treatment, and the destabilizing effects it has on the societies. The devastating consequences of war and the growing numbers of victims cast human rights in a different light. In today's world, the professional domain of health professionals intersects with growing social and political trends, particularly the power of individualism. Emerging social and political dynamics across the globe illustrate how much attention gets focused on the personal and individual. These developments frame an increasingly important role of health 
professionals on national security, peace, and stability. Their increasing involvement draws them into the epicenter of the war and destabilizing conflicts. They are challenged to examine their roles, responsibilities, and ethical practices in combat and related operations.

This book helps health professionals undertake individual self-analysis and better serve in the time-honored role bestowed upon them by tradition. When medicine is practiced in compliance with widely accepted medical ethics, the profession derives great moral authority and legitimacy. Healthcare professions rely on trust, a central pillar of which is the premise that under no circumstances can a practitioner abandon his or her role to competing interests, including the security interests of the government in time of war. 